\title{
Cord levels of zinc and copper in relation to maternal serum levels in different gestational ages
}

\author{
May Abdellatif ${ }^{1}$, Ismail Mohamed Elhawary ${ }^{1}$, Marwa Mohamed Mahmoud ${ }^{2}$, Eman R. Youness ${ }^{3}$ and \\ Walaa Alsharany Abuelhamd ${ }^{1,4^{*}}$
}

\begin{abstract}
Background: A few published data on maternal and cord levels of zinc and copper with conflicting results were reported. We aimed to measure zinc and copper levels in the maternal blood and cord blood of newborns and correlate their levels with the gestational age and anthropometric measurements. This cross-sectional study included 75 full-term and preterm neonates and their mothers. These neonates were divided into 2 groups according to their gestational age. Serum levels of copper and zinc were estimated for the mothers of the studied neonates as well as their cord samples. This was done using atomic absorption spectrophotometry.

Results: The mean cord serum zinc in full term was $0.88 \pm 0.18 \mu \mathrm{g} / \mathrm{ml}$ whereas in preterms was $0.73 \pm 0.13 \mu \mathrm{g} / \mathrm{ml}$. The mean cord copper in full term was $1.37 \pm 0.26 \mu \mathrm{g} / \mathrm{ml}$, whereas in preterms was $0.75 \pm 0.28 \mu \mathrm{g} / \mathrm{ml}$. Comparison between cord zinc and copper levels and maternal levels were statistically significant $(p<0.001)$. A significant positive correlation was found between zinc levels in neonates and their mothers $(r 0.644 ; p<0.000)$ and a similar positive correlation was found between copper levels in neonates and their mothers ( $r 0.625 ; p 0.000$ ). A highly significant positive correlation was found between cord zinc and copper and anthropometric measurements.
\end{abstract}

Conclusion: The present work draws our attention to the significant correlation between trace elements in pregnant mothers and fetal development. Also, prematurity adversely influences zinc and copper levels in neonates.

Keywords: Copper, Zinc, Preterm, Full term, Trace elements

\section{Background}

Trace elements are vital nutrients that cannot be synthesized in the human body [1].

They are important components for transcription factors and function as catalytic cofactors for enzymes regulating cell differentiation and maturation [2].

Zinc and copper are important trace elements that are necessary for optimum human growth and development [3]. Zinc is protective against free radicals and is involved intracellularly in cell division and nucleic acid

\footnotetext{
* Correspondence: walaa_alsharany@hotmail.com

'Department of Pediatrics, Faculty of Medicine, Cairo University, Cairo, Egypt ${ }^{4}$ New Children Hospital (Abu El Rish), Cairo University Hospitals, PO Box

11562, Ali Basha Ebrahim, Cairo, Egypt

Full list of author information is available at the end of the article
}

synthesis. Copper is also an essential cofactor in oxidative and reductase enzymes [4].

Deficiencies of trace minerals have been reported, yet review of literature has not revealed clear recommendations regarding their supplementation [1]. The maternal mineral status during gestation is essential for growth and development of the fetus and subsequent neonatal heath [5].

Since preterm infants are born prior to the time of rapid intrauterine fetal growth, they are vulnerable to deficiencies of essential nutrients for brain development, including zinc and copper [6]. Therefore, these elements need to be studied to supply health personnel with fundamental data necessary for appropriate management. 
There are a few published researches on maternal and cord levels of zinc and copper with inconsistent results. The purpose of this study was to measure zinc and copper levels in the maternal blood and cord blood of newborns and to correlate their levels with the gestational age and anthropometric measurements.

\section{Methods}

\section{Patients and settings}

This cross-sectional study was conducted over a period of 18 months' duration. The study included 75 full-term and preterm neonates of either gender and their mothers. These neonates were divided into 2 groups according to their gestational age. Group 1 consisted of 35 full-term neonates $>37$ weeks of gestation and their mothers, while group 2 consisted of 40 preterm neonates $<37$ weeks of gestation and their mothers. Babies with congenital anomalies such as hydrocephalus, sacral agenesis, or myopathies were excluded from the study as these may affect the anthropometric measurements. Also, babies of mothers with medical problems such as maternal diabetes and hypertension were excluded. An informed consent was taken from the mothers. The study was approved by the Ethics Committee of Pediatric Department, Faculty of Medicine.

\section{Data gathering}

All cases were subjected to assessment by full maternal and neonatal history taking. A detailed maternal history included the age of the mother, parity, previous pregnancies, last menstrual period, complications of pregnancy such as toxemia of pregnancy and antepartum hemorrhage, antenatal vitamin supplementation, and mode of delivery.

Full thorough examination of the neonates was done, and all included neonates had normal chest, cardiac, abdominal, and neurological examination, with good neonatal reflexes and Apgar score.

All the neonates' measurements were taken on birth day including birth weight $(\mathrm{kg})$, birth length $(\mathrm{cm})$, and head circumference $(\mathrm{cm})$ using the tape, measuring the greatest circumference of head passing by the glabella.

Clinical assessment of gestational age was done according to New Ballard score.

Serum levels of copper and zinc were estimated for the mothers of the 75 studied neonates as well as cord samples from them.

\section{Biochemical parameters}

Blood samples were collected using sterile dry disposable syringes for measurement of copper and zinc at the time of birth. Samples were kept at room temperature and left to clot for 30-60 min. Then, tubes were centrifuged at $1500 \mathrm{rpm}$ for $15 \mathrm{~min}$ and separated serum was directly transferred to be kept frozen at $-20{ }^{\circ} \mathrm{C}$ till time of assay. Strict measures to avoid contamination of the samples were taken.

Determination of serum copper and zinc levels was done by atomic absorption spectrophotometry using Varian SpectrAA 220 Flame Atomic Absorption Spectrometer (Varian, Australia). The spectral lines used for determination were $213.9 \mathrm{~nm}$ for $\mathrm{Zn}$ and $324.7 \mathrm{~nm}$ for $\mathrm{Cu}$. The standard sources of the investigated elements were hollow cathode discharge lamps made by Cathodeon, England. The recommended slit widths used for element determination were 1.0 and $0.5 \mathrm{~nm}$ for $\mathrm{Zn}$ and $\mathrm{Cu}$, respectively. The fuel used for the flame was acetylene for the two elements under investigation with oxidizing flame stoichiometry. The oxidant (air) flow rate was $3.5 \mathrm{l} / \mathrm{min}$ and the fuel rate $\left(\mathrm{C}_{2} \mathrm{H}_{2}\right)$ was $1.5 \mathrm{l} / \mathrm{min}$.

Serum samples were diluted five times with double distilled water just before sample measurement. All solutions were prepared with ultrapure water with double distilled water commercially available. One thousandmilligram per liter $\mathrm{Zn}$ and $\mathrm{Cu}$ standard solutions were used (Tritisol, Merck) in order to prepare the working standard solutions. These were freshly prepared and calibration graphs were constructed for each element with suitable standard samples according to the recommendations of the manufacturer of the instrument.

To detect possible interference and matrix effects, the correlation of the absorption with the existing concentration was made by applying the normal calibration graph. No matrix interference for zinc and copper was noted, as it can be deduced from the similarity of slopes corresponding to the two methods used (linear calibration and addition calibration method). No chemical interferences were measured, while measuring the elements of interest in this work. An aliquot of 100- $\mu \mathrm{l}$ sample was aspirated to measure the absorption signal using a homemade Teflon micro-funnel as explained elsewhere.

\section{Statistical analysis}

After collection of the data, they were coded, entered, and processed on computer using Statistical Packaged for Social Science (SPSS version 16, 2007). The level $P<$ 0.05 was considered the cut-off value for significance. Chi-Square test $\chi^{2}$ was used to test the association variables for categorical data. Fisher exact test was performed in table containing value less than 5. Student's $t$-test was used to assess the statistical significance of the difference between two population means in a study involving independent samples. The correlation coefficient method was used to relate different parameter. Linear regression analysis approach to modeling the relationship between a scalar dependent variable and one or more explanatory variables was used. Graphic presentation of the results was also done. 


\section{Results}

A total of 150 subjects were included in this study, 40 preterm neonates and their mothers and 35 full-term neonates and their mothers. The study included 46 females (61.3\%) and 29 males (38.7 \%).

The mean gestational age of the full terms was $39.1 \pm$ 0.85 weeks, and their mean birth weight was $2.96 \pm 0.19$ $\mathrm{kg}$ while the preterms had a mean gestational age of 33.6 \pm 2.5 weeks and a mean birth weight of $1.69 \pm 0.43 \mathrm{~kg}$. Thirty-two full-term neonates and 17 preterms were delivered by normal vaginal delivery while 3 full terms and 23 preterms were delivered by Caesarean section.

The mean cord serum zinc level in full-term neonates was $0.88 \pm 0.18 \mu \mathrm{g} / \mathrm{ml}$, whereas in preterms was $0.73 \pm$ $0.13 \mu \mathrm{g} / \mathrm{ml}$. Also, the mean serum zinc level in mothers of full term was $1.09 \pm 0.15 \mu \mathrm{g} / \mathrm{ml}$, whereas in the mothers of preterms was $0.96 \pm 0.15 \mu \mathrm{g} / \mathrm{ml}$.

The mean cord serum copper in full-term neonates was $1.37 \pm 0.26 \mu \mathrm{g} / \mathrm{ml}$, whereas in preterms was $0.75 \pm$ $0.28 \mu \mathrm{g} / \mathrm{ml}$. Also, the mean serum copper level in mothers of full terms was $1.69 \pm 0.39 \mu \mathrm{g} / \mathrm{ml}$, whereas in the mothers of preterms was $1.40 \pm 0.33 \mu \mathrm{g} / \mathrm{ml}$.

Comparison between cord serum zinc and copper levels and maternal levels proved to be statistically significant $(p<0.001)$ (Table 1$)$.

A significant positive correlation was found between zinc levels in neonates and their mothers $(p<0.05)$; an increasing level of zinc in mothers was associated with an increasing level of zinc in their neonates $(r$ 0.644; $p$ $0.000)$. A similar positive correlation was found between copper levels in neonates and their mothers $(r$ 0.625; $p$ 0.000 ) (Figs. 1 and 2).

A significant difference in both cord copper and zinc was detected in full-term neonates among appropriate (AGA) and small for gestational age (SGA). However, among preterm neonates, cord copper was significantly higher in appropriate for gestational age in comparison to small for gestational age with no difference in cord zinc between the 2 groups (Table 2).

A significant positive correlation was found between cord zinc and copper levels and gestational age. A highly significant positive correlation was found between cord zinc and copper levels and birth weight, birth length, and occipital frontal circumference (Table 3).

Table 1 Comparison between serum zinc and copper levels in cord and maternal blood of preterm and full-term neonates

\begin{tabular}{|c|c|c|c|c|c|c|}
\hline \multirow{2}{*}{$\begin{array}{l}\text { Variable } \\
(\mu \mathrm{g} / \mathrm{ml})\end{array}$} & \multicolumn{2}{|c|}{ Preterm (40) } & \multicolumn{2}{|c|}{ Full term (35) } & \multirow[t]{2}{*}{$T$-test } & \multirow[t]{2}{*}{$P$-value } \\
\hline & Mean & $\pm \mathrm{SD}$ & Mean & $\pm S D$ & & \\
\hline Cord zinc & 0.73 & 0.13 & 0.88 & 0.18 & 4.053 & $<0.001$ \\
\hline Maternal zinc & 0.96 & 0.15 & 1.09 & 0.15 & 3.644 & $<0.001$ \\
\hline Cord copper & 0.75 & 0.28 & 1.37 & 0.26 & 9.899 & 0.000 \\
\hline Maternal copper & 1.40 & 0.33 & 1.69 & 0.39 & 3.491 & 0.001 \\
\hline
\end{tabular}

However, no significant relation was found between zinc levels and sex or mode of delivery. Cord copper levels had a significant relation to the mode of delivery $(p<0.05)$ with no relation to sex.

The maternal serum zinc and copper showed a positive correlation with gestational age and anthropometric measurements of neonates, so higher maternal copper and zinc were associated with larger anthropometric measurements (Table 4).

Among the mothers of the studied neonates, 45 (60\%) were on multivitamin and mineral supplementations during pregnancy, while $30(40 \%)$ were not. Babies of supplemented mothers had statistically significant higher anthropometric measurements than babies of nonsupplemented mothers $(p<0.00)$. However, owing to the low socioeconomic status of the mothers and their inaccurate reporting of the type and duration of supplements, these results are questionable.

In our study, univariate and multivariate linear regression analysis were performed to evaluate the factors affecting weight of neonates. In the stepwise linear regression analysis, the insignificant independent variables were removed one by one (maternal serum zinc and copper level). Other than gestational age, the only variable, neonatal zinc and copper, was independently associated with birth weight. The regression coefficient was (zinc $=0.450,95 \%$ confidence interval was 1420 , and copper $=0.379,95 \%$ confidence interval was 1.009 ) $(P=0.000)$.

\section{Discussion}

Trace elements are essential for all biological cell function. They play an important role during pregnancy and deficiencies during gestation may adversely affect both mother and fetus [7]. Essential elements in pregnant women and the fetus are affected by the major physiological changes occurring during pregnancy, in addition to the other significant factors such as maternal age, week of gestation, nutritional status, and living environment [8].

In the current study, the cord blood levels of copper and zinc in preterm neonates were significantly lower in comparison to full-term neonates. A highly significant positive correlation of serum copper and zinc levels with gestational age $(r=0.305$ and $p=0.008)$ was observed.

The lower serum copper levels in preterms may be attributed to its increased need for fetal growth and development and its important role in erythropoiesis. This is also intensified by the immaturity of the liver to synthesize ceruloplasmin. Preterm and low-birth weight babies have low zinc levels due to deficient body stores, as $60 \%$ of fetal zinc is acquired during the last trimester of pregnancy [9]. 


\section{Zinc in neonates}

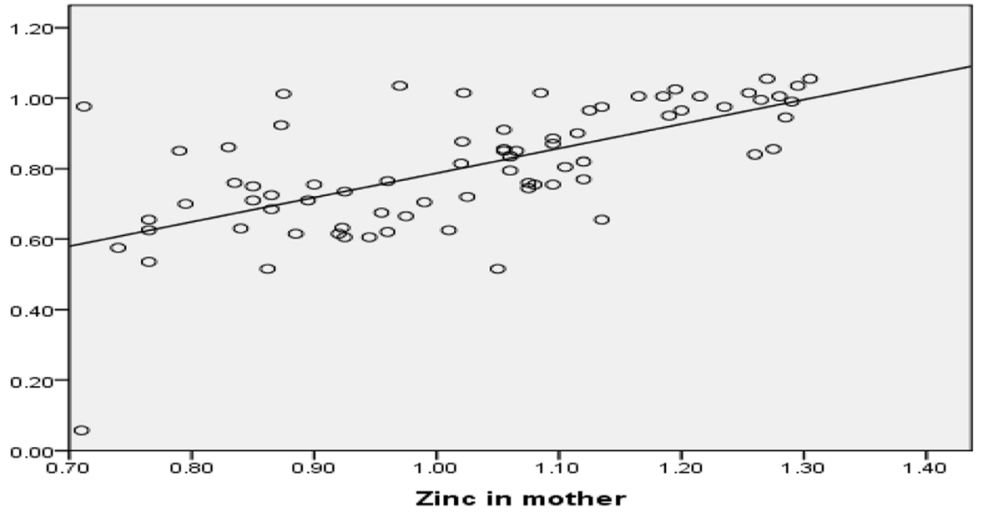

Fig. 1 Correlation between zinc level in neonates and zinc level in mothers

Jafaar et al. reported increasing zinc levels with increasing gestational age [10]. Also, Boskabadi et al. in Japan reported lower cord blood zinc and copper in preterms relative to full-term neonates [11]. On the contrary, no significant difference was found between preterms and full terms in the study done by Sakha et al. in Iran [12]. On the contrary, Kojima et al. found lower zinc levels with increasing gestational age [6].

A significant relation was found between cord copper and zinc levels and the anthropometric measures. Fullterm neonates showed higher levels of cord blood copper and zinc in AGA in comparison to SGA. However, in the preterm group, AGA showed significantly higher serum copper levels than SGA with no difference in serum zinc levels. So more mature babies had higher zinc and copper levels and the higher the level, the greater were the anthropometric measurements indicating more growth.

Amalia et al. reported that zinc and copper levels in normal neonates were significantly higher than in neonates with fetal growth restriction. Fetal growth restriction can occur due to placental insufficiency which causes defects in placental circulation and transport affecting nutrient transport [13]. The results of Zadrozna et al. research in Poland found a decrease in zinc levels by $37 \%$ and copper by $27 \%$ in neonates born with fetal growth restriction [14].

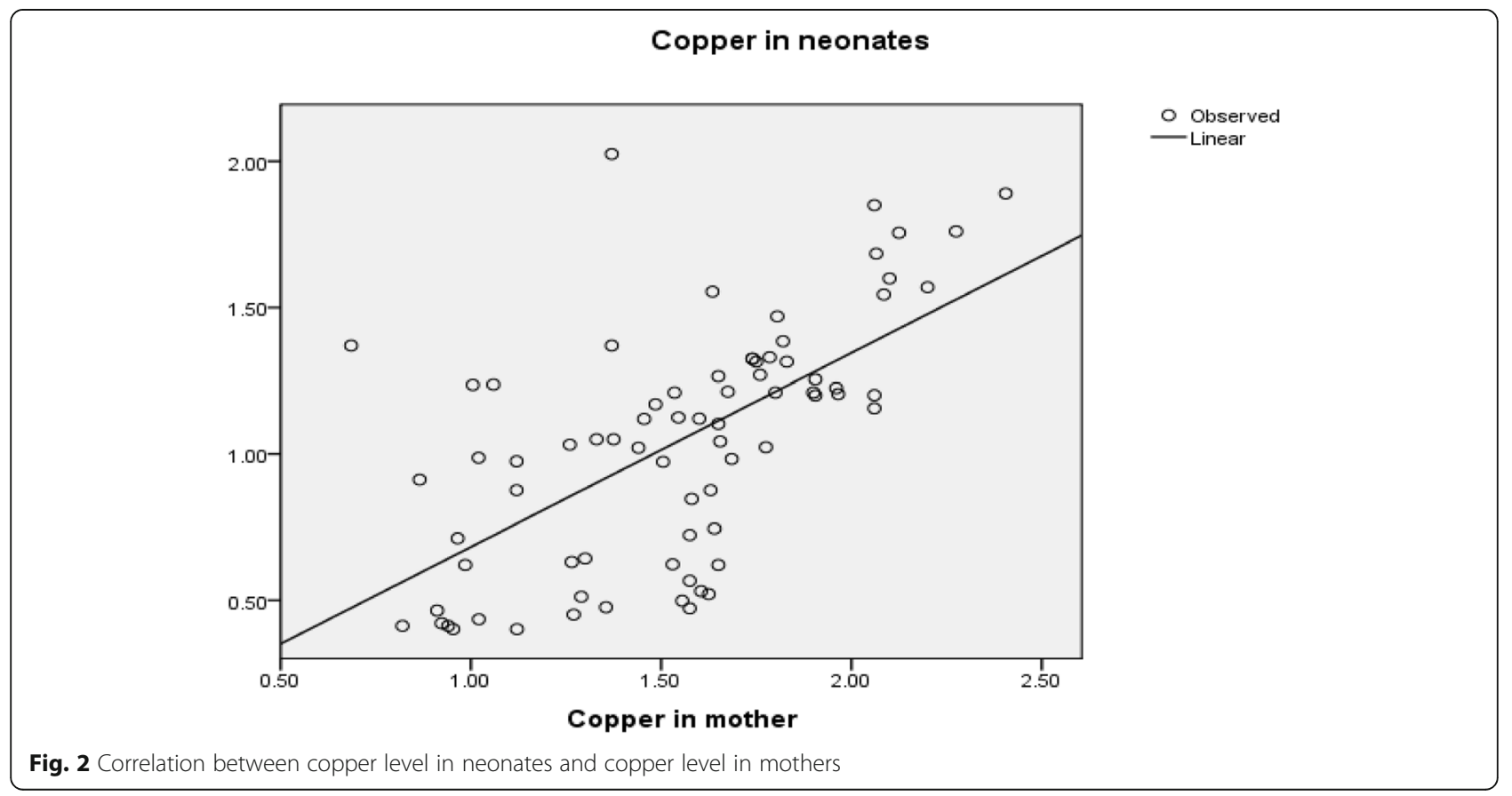


Table 2 Comparison between cord copper and zinc levels in AGA and SGA preterms and full terms

\begin{tabular}{|c|c|c|c|c|}
\hline \multirow[t]{3}{*}{ Variable } & \multicolumn{2}{|l|}{ Preterms } & \multirow[t]{3}{*}{$T$-test } & \multirow[t]{3}{*}{$P$-value } \\
\hline & AGA $(N=26)$ & \multirow[t]{2}{*}{$\mathrm{SGA}(N=14)$} & & \\
\hline & Mean \pm SD & & & \\
\hline Copper ( $\mu \mathrm{g} / \mathrm{ml})$ & $0.951 \pm 0.259$ & $0.638 \pm 0.221$ & -3.526 & 0.001 \\
\hline \multirow[t]{4}{*}{ Zinc ( $(\mathrm{gg} / \mathrm{ml})$} & $0.728 \pm 0.141$ & $0.746 \pm 0.121$ & -.404 & 0.689 \\
\hline & Full terms & & \multirow[t]{3}{*}{$T$} & \multirow[t]{3}{*}{$P$-value } \\
\hline & $\mathrm{AGA}(N=29)$ & $\operatorname{SGA}(N=6)$ & & \\
\hline & Mean \pm SD & & & \\
\hline Copper $(\mu \mathrm{g} / \mathrm{ml})$ & $1.419 \pm 0.258$ & $1.154 \pm 0.139$ & 2.421 & 0.021 \\
\hline Zinc ( $\mu \mathrm{g} / \mathrm{ml})$ & $0.9118 \pm 0.1906$ & $0.7508 \pm 0.072$ & 2.027 & 0.051 \\
\hline
\end{tabular}

AGA appropriate for gestational age, SGA small for gestational age

Ofakunrin et al. [15] and Abbas et al. [16] demonstrated a significant positive association between cord zinc concentration and birth weight, which suggests that zinc is an important element for fetal growth and development. Sultana et al. in agreement with our work showed a positive correlation between serum copper and mean birth weight of preterm and full-term neonates [17].

On the other hand, Kojima et al. [6] reported no difference in zinc levels in SGA than AGA preterm neonates similar to our results but they found higher copper levels in SGA rather than AGA. A study done in Bangladesh by Islam et al. [18] reported no significant difference in serum zinc level between preterm SGA and AGA babies. Also, Xiang and colleagues reported that serum zinc level in umbilical cord blood had no statistically significant effect on SGA and LGA [19].

Contrary to this work, evaluation of ten trace elements by Bermudez and colleagues showed that cord copper was the only one inversely and independently related to birth weight with highest concentrations found in the SGA group [20]. Marriott et al. reported no significant associations between height, weight, and head circumference with trace element levels except for a weak correlation between copper at term and head circumferences [21].

In the present study, comparing the maternal and neonatal levels revealed that the maternal serum copper and zinc levels were higher than the cord copper and zinc levels. A positive correlation was found between maternal and neonatal zinc and copper levels $(r=0.644$ and $p=0.000 ; r=0.625$ and $p=0.000$, respectively).

The higher maternal copper levels can be explained by the transfer of stored copper in maternal tissues (specially the liver) to the growing fetus. Also, the concentration of ceruloplasmin is elevated during gestation with an increased level in maternal blood than in cord blood [22]. Bermudez et al. also reported a positive correlation between cord copper and maternal serum levels [20].

However, Tsuzuki et al. [23] and Ofakunrin et al. [15] reported no significant difference between neonatal and maternal zinc and copper concentrations.

Other studies [5, 22, 24] found lower concentrations of copper and a higher level of zinc in cord blood than in maternal blood. The reduction in maternal zinc levels may be explained by numerous factors including elevated zinc uptake by the fetus and placenta, increased mobilization of plasma zinc to maternal erythrocytes, physiological dilution secondary to enhanced maternal blood volume, and reduced serum albumin for zinc binding during pregnancy. In addition, zinc transporters, as $\mathrm{ZnT}$, present in the placenta, accelerate zinc uptake from the maternal blood to the fetus. Also, previous studies done by Sakha et al. [12] and Iqbal et al. [25] reported significantly lower maternal zinc levels in comparison to their neonates.

Lower zinc and copper in mothers of preterms was found in relation to zinc and copper of mothers of full terms. This is also confirmed by Sultana et al. [17] in Bangladesh who suggested that during pregnancy high

Table 3 Correlation of cord zinc and copper levels with the anthropometric measurements in the studied neonates

\begin{tabular}{|c|c|c|c|c|}
\hline \multirow[t]{2}{*}{ Variable } & \multicolumn{2}{|l|}{ Cord zinc } & \multicolumn{2}{|l|}{ Cord copper } \\
\hline & Correlation coefficient $(r)$ & $P$-value & Correlation coefficient $(r)$ & $P$-value \\
\hline Gestational age (weeks) & 0.305 & 0.008 & 0.851 & $<0.001$ \\
\hline Birth weight (kg) & 0.450 & $<0.001$ & 0.861 & $<0.001$ \\
\hline Birth length $(\mathrm{cm})$ & 0.421 & $<0.001$ & 0.893 & $<0.001$ \\
\hline Occipito-frontal circumference $(\mathrm{cm})$ & 0.277 & 0.018 & 0.839 & $<0.001$ \\
\hline
\end{tabular}


Table 4 Correlation of maternal serum zinc and copper levels with the anthropometric measurements in all the studied neonates

\begin{tabular}{|c|c|c|c|c|}
\hline \multirow[t]{2}{*}{ Variable } & \multicolumn{2}{|l|}{ Maternal serum zinc } & \multicolumn{2}{|l|}{ Maternal serum copper } \\
\hline & Correlation coefficient $(r)$ & $P$-value & Correlation coefficient $(r)$ & $P$-value \\
\hline Gestational age(weeks) & 0.558 & 0.000 & 0.602 & 0.000 \\
\hline Birth weight(kg) & 0.540 & 0.000 & 0.529 & 0.000 \\
\hline Birth length $(\mathrm{cm})$ & 0.560 & 0.000 & 0.576 & 0.000 \\
\hline Occipito-frontal circumference $(\mathrm{cm})$ & 0.500 & 0.000 & 0.629 & 0.000 \\
\hline
\end{tabular}

levels of estrogen increase ceruloplasmin resulting in increased serum copper in full-term mothers.

Also Maamouri and colleagues stated the presence of a significant association between low birth weight and maternal zinc levels [4]. Many researchers around the world who found a positive correlation between maternal serum zinc and birth weight reported mothers with lower zinc levels to be 2.6 times more liable to deliver LBW babies than those with normal levels, and neonates with decreased zinc levels were 2.8 times more at risk of being LBW [10, 26, 27].

In the present study, there was no relation between the sex and level of serum zinc and copper. Zych and colleagues reported that neonatal gestational age, gender, and birth weight had no substantial impact on concentrations of trace elements in the cord blood except concentrations of iron which was statistically significantly correlated with gender of neonates [28].

In our study, univariate and multivariate linear regression analysis were performed to evaluate the factors affecting weight of neonates. Other than gestational age, only neonatal zinc and copper were independently associated with birth weight.

\section{Conclusion}

The present work draws our attention to the significant correlation between trace elements in pregnant mothers and fetal development through analysis of the anthropometric measurements of neonates. In addition, prematurity adversely influences zinc and copper levels in neonates. These results may help in establishing guidelines for supplementation of trace elements.

\section{Limitation}

This study had several limitations; the population size needs to be larger in order to observe better results in subgroups and we did not analyze the dietary intake and nutritional status of pregnant women which may affect maternal concentrations of trace elements.

\section{Abbreviations}

AGA: Appropriate for gestational age; SGA: Small for gestational age; ZnT: Zinc transporters

\section{Acknowledgements}

None
Authors' contributions

MA: conception and design of study, shared in analysis and interpretation of data, critical revision of the article, and final approval of the version to be published. IE: shared in data acquisition and analysis and critical revision for important intellectual content. MM: shared data collection and interpretation of data, drafting of the article, and final approval for publishing. EY: carried out all technical process concerned with laboratory section of the serum zinc and copper analysis. WA: shared in data acquisition and critical revision for important intellectual contents and final approval for publishing and proceeded through submission steps. All authors have read and approved the manuscript.

Funding

The study does not have a funding source.

\section{Availability of data and materials}

The datasets used and/or analyzed during the current study are available from the corresponding author on reasonable request.

\section{Declarations}

Ethics approval and consent to participate

The study was approved by the Ethics Committee of Pediatric Department, Faculty of Medicine, Cairo University.

The committee reference number is not applicable.

Informed verbal consent was taken from the mothers during delivery and this was approved by the ethical committee.

\section{Consent for publication}

Not applicable

\section{Competing interests}

The authors declare no competing interests.

\section{Author details}

${ }^{1}$ Department of Pediatrics, Faculty of Medicine, Cairo University, Cairo, Egypt. ${ }^{2}$ Department of Pediatrics, Ministry of Health, Cairo, Egypt. ${ }^{3}$ Department of Medical Biochemistry, National Research Center, Cairo, Egypt. ${ }^{4}$ New Children Hospital (Abu El Rish), Cairo University Hospitals, PO Box 11562, Ali Basha

Ebrahim, Cairo, Egypt.

Received: 26 January 2021 Accepted: 12 March 2021

Published online: 05 April 2021

References

1. Finch CW (2015) Review of trace mineral requirements for preterm infants: what are the current recommendations for clinical practice? Nutr Clin Pract 30(1):44-58. https://doi.org/10.1177/0884533614563353

2. Thiele DJ (2003) Integrating trace element metabolism from the cell to the whole organism. J Nutr 133(5):1579S-1580S. https://doi.org/10.1093/jn/133. 5.15795

3. Griffin IJ, Domellöf M, Bhatia J, Anderson DM, Kler N (2013) Zinc and copper requirements in preterm infants: an examination of the current literature. Early Hum Dev 89:S29-S34. https://doi.org/10.1016/j.earlhumdev.2013.08.001

4. Maamouri G, Boskabadi H, Noria M et al (2011) Maternal and neonatal zinc and copper levels and birth weight. Iran J Neonatol 2(1):26-31

5. Kocyłowski R, Lewicka I, Grzesiak M, Gaj Z, Oszukowski P, von Kaisenberg C, Suliburska J (2018) Evaluation of mineral concentrations in maternal serum before and after birth and in newborn cord blood postpartum—preliminary 
study. Biol Trace Elem Res 182(2):217-223. https://doi.org/10.1007/s12011-01 7-1109-9

6. Kojima C, Shoji H, Ikeda N, Kitamura T, Hisata K, Shimizu T (2017) Association of zinc and copper with clinical parameters in the preterm newborn. Pediatr Int 59(11):1165-1168. https://doi.org/10.1111/ped.13409

7. Spencer BH, Vanderlelie JJ, Perkins AV (2015) Essentiality of trace element micronutrition in human pregnancy: a systematic review. J Preg Child Health 2(157):1-7

8. Kocyłowski R, Grzesiak M, Gaj Z, Lorenc W, Bakinowska E, Barałkiewicz D, von Kaisenberg CS, Suliburska J (2019) Evaluation of essential and toxic elements in amniotic fluid and maternal serum at birth. Biol Trace Elem Res 189(1): 45-54. https://doi.org/10.1007/s12011-018-1471-2

9. Sazawal S, Black RE (2010) Effect of oral zinc supplementation on the growth of preterm infants. Indian Pediatr 47(10):841-842. https://doi.org/1 0.1007/s13312-010-0139-6

10. Jaafar ZA, Salman DA, Obeid RZ (2018) The role of maternal and fetal serum zinc level in low birth weight. J Pharm Sci Res 10(8):2115-2118

11. Boskabadi H, Maamouri G, Nori M, Mohsenzadeh H, Ayatollahi H, GhayourMobarhan M, Sahebkar A, Heshmati A, Ferns GAA (2012) Maternal and neonatal serum concentrations of zinc and copper in preterm delivery: an observational study. Trace Elem Electroly 29(4):232-238. https:/doi.org/10. 5414/TEX01244

12. Sakha K, Rahimi AO, Rohi AJ, Abasalizadeh SH (2005) Comparison of serum zinc and copper levels between term and preterm neonates cord blood and their mothers' blood. Iran J Pediatr 15(3):255-260

13. Amalia M, Yusrawati Y, Sukma R (2018) Differences of zinc and copper levels in placenta blood normal neonates and intrauterine growth restriction. Midwifery 3(2):19-26. https://doi.org/10.25077/jom.3.2.19-26.2018

14. Zadrożna M, Gawlik M, Nowak B, Marcinek A, Mrowiec H, Walas S, WietechaPosłuszny R, Zagrodzki P (2009) Antioxidants activities and concentration of selenium, zinc and copper in preterm and IUGR human placentas. J Trace Elem Med Biol 23(2):144-148. https://doi.org/10.1016/j.jtemb.2009.02.005

15. Ofakunrin AO, Collins J, Diala UM, Afolaranmi TO, Okolo SN (2017) Relationship between maternal serum zinc, cord blood zinc and birth weight of term newborn infants in Jos, Plateau State, Nigeria. Jos J Med 11(2):12-20

16. Abass RM, Hamdan HZ, Elhassan EM, Hamdan SZ, Ali NI, Adam I (2014) Zinc and copper levels in low birth weight deliveries in Medani Hospital, Sudan. BMC Res Notes 7(1):386

17. Sultana M, Jahan N, Sultana N, Akter R (2012) Serum copper and plasma protein status in preterm delivery. J Bangladesh Soc Physiol 7(1):41-47

18. Islam MN, Chowdhury AK, Siddika M, Hossain MA, Hossain MK (2009) Effect of zinc on growth of preterm babies. Mymensingh Med J 18(1):125-130

19. Xiang HY, Liang CM, Yan SQ et al (2018) The relationship of maternal and umbilical cord blood zinc level associated with newborn birth weight: a birth cohort study. Zhonghua Yu Fang Yi Xue Za Zhi 52(10):1008-1012

20. Bermúdez L, García-Vicent C, López J, Torró MI, Lurbe E (2015) Assessment of ten trace elements in umbilical cord blood and maternal blood: association with birth weight. J Transl Med 13(1):291. https://doi.org/10.11 86/s12967-015-0654-2

21. Marriott LD, Foote KD, Kimber AC, Delves HT, Morgan JB (2007) Zinc, copper, selenium and manganese blood levels in preterm infants. Arch Dis Child Fetal Neonatal Ed 92(6):F494-F497. https://doi.org/10.1136/a dc.2006.107755

22. Awadallah SM, Abu-Elteen KH, Elkarmi AZ, Qaraein SH, Salem NM, Mubarak MS (2004) Maternal and cord blood serum levels of zinc, copper, and iron in healthy pregnant Jordanian women. J Trace Elem Exp Med 17(1):1-8. https://doi.org/10.1002/jtra.10032

23. Tsuzuki S, Morimoto N, Hosokawa S, Matsushita T (2013) Associations of maternal and neonatal serum trace element concentrations with neonatal birth weight. PLoS One 8(9):e75627. https://doi.org/10.1371/journal.pone. 0075627

24. Upadhyaya C, Mishra S, Ajmera P, Sharma P (2004) Serum iron, copper and zinc status in maternal and cord blood. Indian J Clin Biochem 19(2):48-52. https://doi.org/10.1007/BF02894257

25. Iqbal AS, Shahidullah M, Islam MN, Akhter S, Banu S (2001) Serum zinc and copper levels in the maternal blood and cord blood of neonates. Indian J Pediatr 68(6):523-526. https://doi.org/10.1007/BF02723246

26. Jyotsna S, Amit A, Kumar A (2015) Study of serum zinc in low birth weight neonates and its relation with maternal zinc. J Clin Diagn Res 9(1):SC01SC03. https://doi.org/10.7860/JCDR/2015/10449.5402
27. Rwebembera AA, Munubhi EK, Manji KP, Mpembeni R, Philip J (2005) Relationship between infant birth weight $\leq 2000 \mathrm{~g}$ and maternal zinc levels at Muhimbili National Hospital, Dar Es Salaam, Tanzania. J Trop Pediatr 52(2): 118-125. https://doi.org/10.1093/tropej/fmi077

28. Zych B, Sztanke M, Kulesza-Bronczyk B, Lewandowski B, Sztanke K, Pasternak K (2013) The analysis of selected microelements in neonatal umbilical cord blood. J Elem 18(3):495-506

\section{Publisher's Note}

Springer Nature remains neutral with regard to jurisdictional claims in published maps and institutional affiliations.

\section{Submit your manuscript to a SpringerOpen ${ }^{\circ}$ journal and benefit from:}

- Convenient online submission

- Rigorous peer review

- Open access: articles freely available online

- High visibility within the field

- Retaining the copyright to your article

Submit your next manuscript at $\boldsymbol{\nabla}$ springeropen.com 